
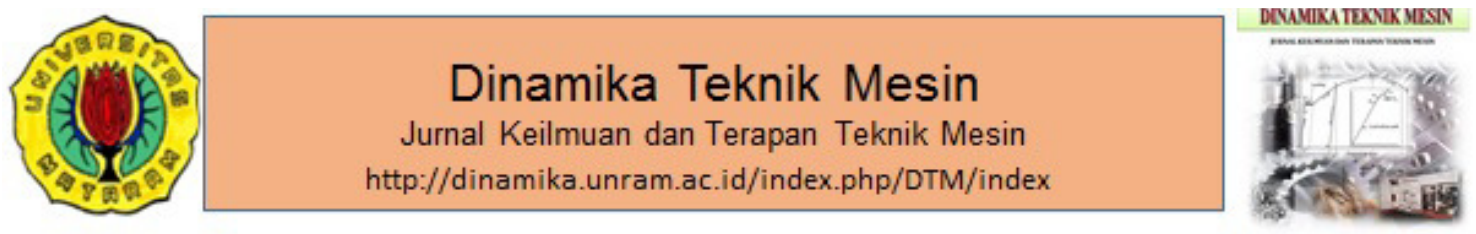

\title{
Peningkatan konduktivitas termal lemak sapi sebagai bahan PCM dengan menambahkan arang sekam padi
}

\section{Increasing thermal conductivity of beef tallow as PCM material with the addition of rice husk char}

I.M. Astika*, I.N.S. Winaya, I.D.G.A. Subagia, I.K.G. Wirawan, I.G.K. Dwijana, I.G.K. Sukadana

Program Studi Teknik Mesin, Fakultas Teknik, Universitas Udayana, Jl. Raya Kampus Bukit Jimbaran Badung Bali, 80361, Indonesia. HP. 08164748992.

`E-mail: made_astika@unud.ac.id

\section{ARTICLE INFO}

Article History:

Received 26 June 2020

Accepted 20 January 2021

Available online 01 April 2021

Keywords:

Beef tallow

Rice husk char

Thermal conductivity

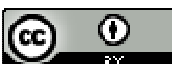

\section{ABSTRACT}

\begin{abstract}
Phase change material (PCM) is a material that can absorb and store energy and can release it based on the principle of latent heat energy storage. Beef tallow is one of the materials that can be used as PCM but its low thermal conductivity is around $0.181 \mathrm{~W} / \mathrm{mK}$. Hence, thermal conductivity is considered an important factor in the conduction heat transfer. This further affects kinetic absorption and heat release. However it is possible to increase the values by adding another material that has a high thermal conductivity. The purpose of this study is to elevate the thermal conductivity of beef tallow by adding rice husk char. This research involves direct incorporation method, where beef tallow is thawed and mixed with the rice husk char then stirred with a rotation of $100 \mathrm{rpm}$ until the mixture becomes solid. Addition of rice husk char with weight fractions of 5 and $10 \%$ and grain size of $0.045 \mathrm{~mm}$. Subsequently, thermal conductivity test was performed using the TQ Heat Transfer Experiment Base Unit.The results show that with the addition of rice husk can increase the thermal conductivity of PCM beef tallow. The increase obtained in the addition of $10 \%$ rice husk char is 37 times compared to the pure sample. Based on this result it is concluded that carbon-based materials such as rice husk char can be used to increase the thermal conductivity of PCM materials.
\end{abstract}

\section{PENDAHULUAN}

Penggunaan sumber energi yang bersumber dari bahan bakar fosil yang selama ini digunakan oleh masyarakat di seluruh dunia berdampak terhadap lingkungan seperti terjadinya perubahan iklim akibat pemanasan global (Conti dkk., 2016). Suatu alternatif untuk mengurangi dampak negatif terhadap lingkungan adalah dengan mengurangi penggunaan energi yang bersumber dari bahan bakar fosil serta meningkatkan penggunaan teknologi energi baru terbarukan yang ramah lingkungan (Bhattacharya dkk., 2016; Stram, 2016). Salah satu teknologi yang dapat menghemat penggunaan 
energi adalah sistem penyimpanan energi panas (thermal energy storage) yang dapat memberikan fleksibilitas untuk memenuhi tantangan di sektor pemanasan dan pendinginan (Nazir dkk., 2019).

Material yang dapat menyerap dan menyimpan energi khususnya energi panas ketika ada surplus dan melepaskannya ketika ada defisit menggunakan prinsip penyimpanan panas laten disebut bahan berubah fase (phase change material/PCM). PCM telah menunjukkan potensi yang besar untuk digunakan sebagai cadangan panas yang aman dan terjangkau dalam sistem energi masa depan (Silva dkk., 2016).

Lemak sapi (beef tallow) merupakan bahan PCM yang secara umum memiliki sifat yang sama dengan lilin (paraffin) yang merupakan salah satu PCM yang sudah banyak diaplikasikan. Namun lemak sapi memiliki temperatur perubahan fase yang lebih rendah. Menurut analisis termal, perubahan fase lemak sapi terjadi dekat dengan suhu normal tubuh manusia yaitu sekitar $36{ }^{\circ} \mathrm{C}$ (Moraes dkk., 2017). Temperatur perubahan fase merupakan salah satu acuan yang dapat digunakan dalam pemilihan bahan PCM untuk suatu aplikasi. Lemak sapi dengan temperatur perubahan fasenya dapat diaplikasikan untuk sistem yang berkaitan dengan kenyamanan.

Lemak sapi seperti bahan PCM organik pada umumnya memiliki konduktivitas termal yang rendah. Konduktivitas termal yang rendah akan membatasi kinetika penyerapan dan pelepasan panas pada saat diaplikasikan untuk sistem penyimpanan panas (Lin dkk., 2018; Suarsana dkk., 2018).

Metode untuk mengatasi keterbatasan konduktivitas termal bahan PCM pada umumnya dengan menambahkan bahan yang memiliki konduktivitas termal tinggi dan dengan metode PCM dalam bentuk kapsul. Material berbasis karbon adalah salah satu aditif paling populer karena konduktivitas termal yang tinggi, sifat kimia yang stabil, kegunaan yang luas dan densitasnya rendah (Wang dkk., 2012). Arang sekam padi merupakan bahan yang memiliki karakteristik sebagai aditif yang dapat digunakan untuk meningkatkan konduktivitas termal bahan PCM (Prusty dkk., 2016).

Berdasarkan uraian diatas maka dalam penelitian ini di lakukan pengujian untuk mendapatkan konduktivitas termal dari bahan PCM yaitu lemak sapi dengan menambahkan arang sekam padi sehingga dapat digunakan dalam sistem penyimpanan panas.

\subsection{Material berubah fase}

Penyimpanan panas laten adalah salah satu cara paling efisien untuk menyimpan energi panas. Prinsipnya adalah energi disimpan selama perubahan fase (misalnya peleburan, penguapan dan kristalisasi). Karena panas spesifik dan perubahan entalpi yang tinggi selama perubahan fase, perubahan panas laten biasanya lebih besar dari perubahan panas konvensional (Jeon dkk., 2019). Berbeda dengan metode penyimpanan panas konvensional, metode penyimpanan panas laten menghasilkan kerapatan penyimpanan yang jauh lebih tinggi dengan perbedaan suhu yang lebih kecil antara menyimpan dan melepaskan panas. Pada dasarnya setiap material menyerap panas dan selama proses pemanasan suhu terus meningkat. Selanjutnya panas yang tersimpan dalam material dilepaskan ke lingkungan melalui proses pendinginan. Selama proses pendinginan, suhu material akan terus menurun (Abu-Jdayil dkk., 2019). Gambar 1 menunjukkan prinsip dasar dari material berubah fase (Astika dkk., 2019).

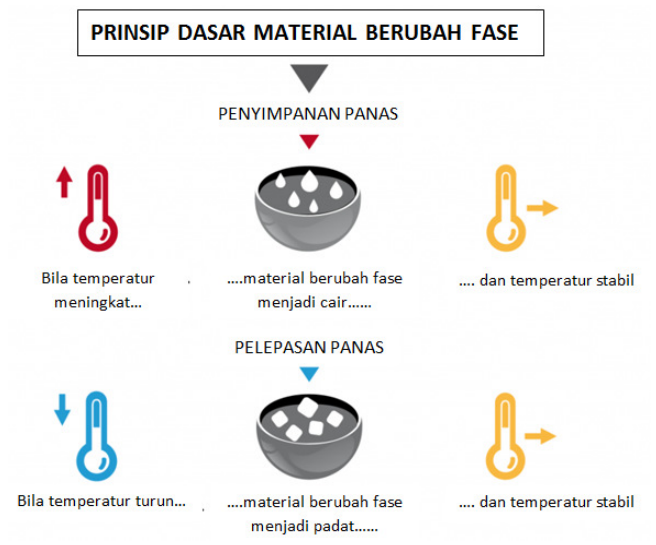

Gambar 1. Prinsip dasar material berubah fase. Sumber: (Memon, 2014) 


\subsection{Peningkatan konduktivitas termal}

Meskipun menjanjikan, kemampuan atau daya serap dari teknologi penyimpanan energi panas (LHTES) dibatasi oleh beberapa hambatan, diantaranya konduktivitas termal yang rendah dari PCM yang akan membatasi kinetika pengisian dan pemakaian serta biaya tinggi pada bahan baku dan proses manufaktur (Lin dkk., 2018).

Secara umum ada dua cara yang digunakan untuk mengatasi keterbatasan konduktivitas termal dari bahan $P C M$ yaitu dengan penambahan bahan pengisi yang memiliki konduktivitas termal tinggi atau metode pengkapsulan seperti ditunjukkan pada gambar 2 (Astika dkk., 2019).

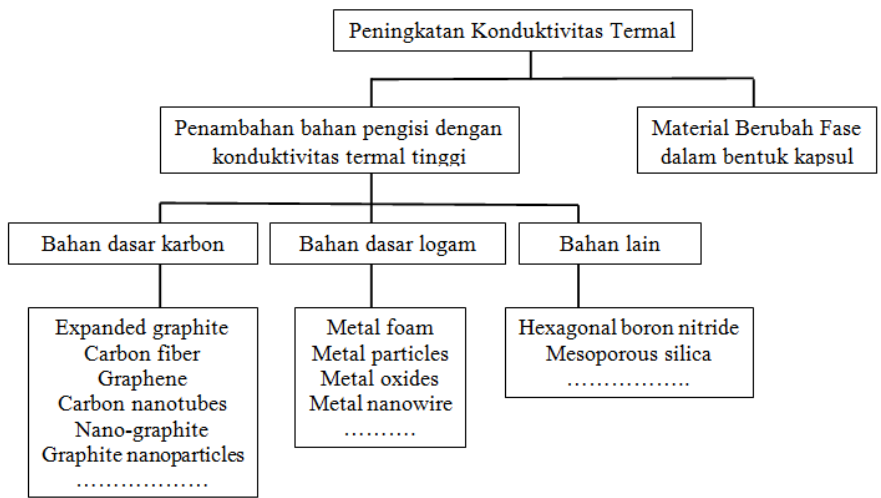

Gambar 2. Metode untuk meningkatkan konduktivitas termal PCM. Sumber: (Lin dkk, 2018)

\section{METODE PENELITIAN}

Penelitian ini merupakan penelitian eksperimental dengan menggunakan alat uji seperti sajikan pada gambar 3 dan 4 . Bahan penelitian adalah lemak sapi dan arang sekam padi. Metode yang digunakan untuk menambahkan arang sekam padi pada lemak sapi adalah dengan pencampuran secara langsung. Lemak sapi dalam keadaan cair dicampurkan dengan arang sekam padi selanjutnya diaduk sampai bahan menjadi padat. Pengadukan menggunakan mixer dengan putaran $100 \mathrm{rpm}$. Variasi fraksi berat dari arang sekam padi adalah 5 dan 10\% yang ditimbang menggunakan timbangan digital dengan akurasi dua angka dibelakang koma. Ukuran butir diperoleh dari hasil pengayakan menggunakan ayakan dengan ukuran $0,045 \mathrm{~mm}$. Pengujian yang dilakukan untuk mendapatkan konduktivitas termal menggunakan alat uji Heat Transfer Experiment Base Unit merek $T Q$. Spesifikasi alat dan bahan yang digunakan dalam penelitian ini dapat dilihat pada tabel 1.

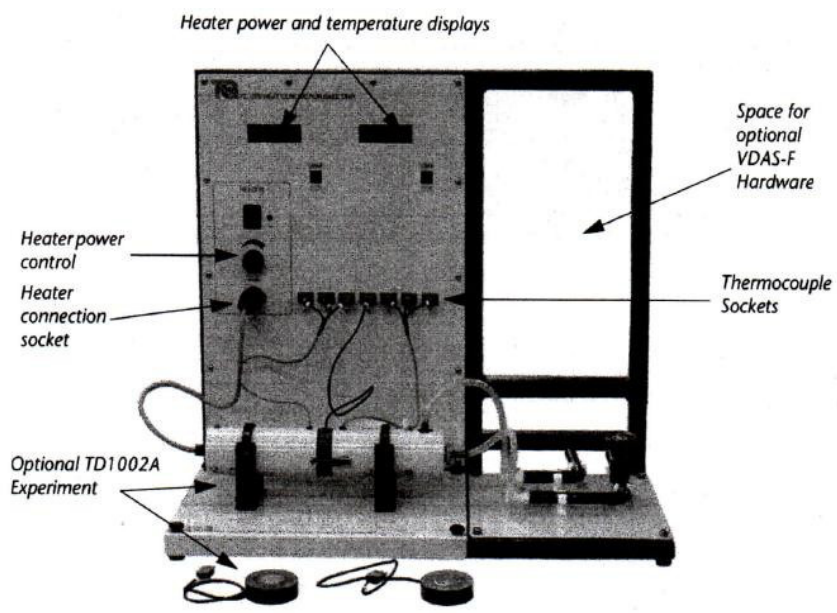

Gambar 3. Aparatus eksperimen (Heat Transfer Experiment Base Unit Merek TQ) 


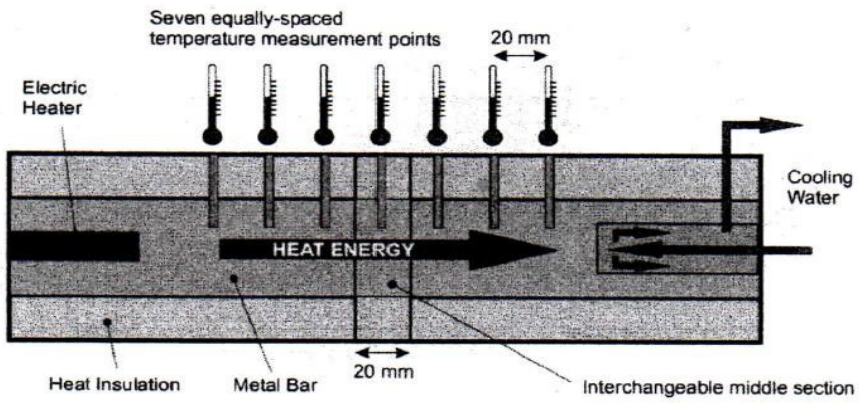

Gambar 4. Skema aparatus.

Tabel 1. Alat dan bahan

\begin{tabular}{ll}
\hline Nama & Spesifikasi \\
\hline Alat uji & Heat Transfer Experiment Base Unit Merek TQ \\
& $1: 0,15$ dan 0,3 Ampere \\
& V :220 Volt \\
Spesimen & $\varnothing 3 \times 2 \mathrm{~cm}$, lemak sapi dan arang sekam padi \\
Bahan isolasi & Polyester Yucalak BQTN Ex 150 dengan $1 \%$ hardener \\
& (MEXPO) \\
Kulit luar & Pipa PVC Ø 2" \\
\hline
\end{tabular}

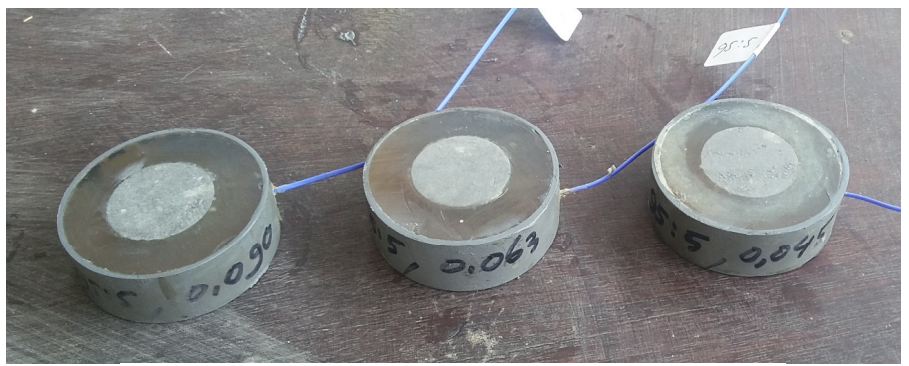

Gambar 5. Spesimen uji konduktivitas thermal

Prinsip kerja dari Heat Transfer Experiment Base Unit merek $T Q$ adalah dengan menggunakan sumber panas pada sisi kiri dan penyerap panas pada sisi kanan sehingga ada perbedaan temperatur sepanjang bahan yang diuji. Sumber panas berasal dari pemanas listrik, benda uji beserta pemanasnya semua diisolasi. Benda uji memiliki tebal $20 \mathrm{~mm}$ dan diameter $30 \mathrm{~mm}$ Energi yang terjadi pada heater di berikan oleh persamaan:

$W=V \times I$

Besarnya energi yang digunakan diatur dengan menggunakan heater power control yang terdapat pada alat uji.

Perpindahan panas yang terjadi:

$\dot{q}=-k A \frac{d T}{d x}$

untuk kasus ini $\mathrm{W}=\mathrm{q}$ dan diasumsikan kebocoran atau loses yang terjadi sangat kecil dan bisa diabaikan. Hal ini dapat dipantau dari display alat uji yang menampilkan temperatur pada heater.

\section{HASIL DAN PEMBAHASAN}

Hasil pengujian konduktivitas termal dari bahan PCM lemak sapi yang ditambahkan bahan aditif berupa arang sekam padi dengan variasi fraksi berat 0,5 dan 10\% ditampilkan pada tabel 2 . 
Dinamika Teknik Mesin. I M Astika dkk.: Peningkatan konduktivitas termal lemak sapi sebagai bahan PCM dengan menambahkan arang sekam padi

Tabel 2. Konduktivitas termal lemak sapi dengan penambahan arang sekam padi

\begin{tabular}{ccccc}
\hline No & $\begin{array}{c}\text { Fraksi berat } \\
\text { lemak sapi } \\
(\%)\end{array}$ & $\begin{array}{c}\text { Fraksi berat } \\
\text { arang sekam } \\
\text { padi }(\%)\end{array}$ & $\begin{array}{c}\text { Ukuran butir arang } \\
\text { sekam padi }(\mathrm{mm}) \\
(k=41 \mathrm{~W} / \mathrm{m} \mathrm{K})\end{array}$ & $\begin{array}{c}\text { Konduktivitas } \\
\text { termal }(\mathrm{W} / \mathrm{m} \mathrm{K})\end{array}$ \\
\hline 1 & 100 & 0 & & 0,1810 \\
2 & 95 & 5 & 0,045 & 6,7406 \\
3 & 90 & 10 & & 6,7472 \\
\hline
\end{tabular}

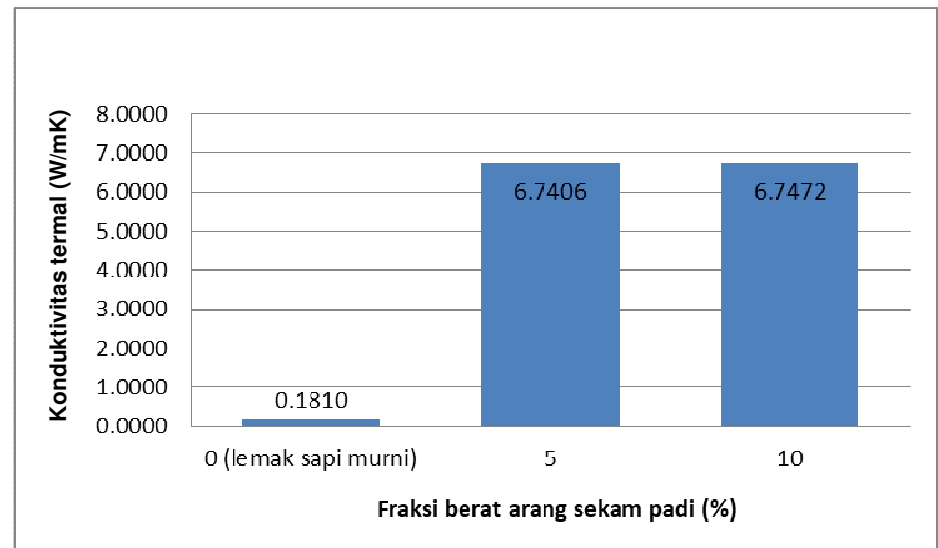

Gambar 6. Perbandingan konduktivitas termal PCM lemak sapi dengan penambahan arang sekam padi

Gambar 6 menyajikan perbandingan konduktivitas termal dari lemak sapi dengan penambahan arang sekam padi. Dibandingkan dengan lemak sapi murni, penambahan arang sekam padi pada lemak sapi dapat meningkatkan konduktivitas termal PCM lemak sapi lebih dari 37 kali. Arang sekam padi merupakan suatu material dengan bahan dasar karbon. Penggunaan bahan berbasis karbon sebagai aditif memiliki kelebihan yaitu konduktivitas termal yang tinggi. Konduktivitas termal yang tinggi dari aditif bermanfaat untuk meningkatkan konduktivitas termal bahan PCM. Penambahan arang sekam padi sebesar 5 dan 10\% tidak menunjukkan peningkatan yang signifikan. Hasil pengujian menunjukkan terjadi peningkatan sebesar $0,9 \%$ pada penambahan $10 \%$ dibandingkan penggunaan $5 \%$ arang sekam padi.

Hasil penelitian menggunakan berbagai jenis material dengan bahan dasar karbon telah dilakukan oleh beberapa peneliti seperti terangkum dalam tabel 2. Dibandingkan dengan hasil penelitian yang sudah dilakukan, penggunaan arang sekam padi menghasilkan peningkatan yang cukup tinggi namun masih berada disekitar hasil yang dilaporkan oleh peneliti sebelumnya. Dengan demikian, arang sekam padi dapat digunakan untuk meningkatkan konduktivitas termal bahan PCM khususnya yang akan diaplikasikan sebagai sistem penyimpanan panas.

Tabel 3. Perbandingan konduktivitas termal dengan penambahan material berbahan dasar karbon

\begin{tabular}{lllllll}
\hline PCM & $\begin{array}{l}\text { Konduktivitas } \\
\text { termal PCM } \\
(\mathrm{W} / \mathrm{m} . \mathrm{K})\end{array}$ & $\begin{array}{l}\text { Material } \\
\text { dengan bahan } \\
\text { dasar karbon }\end{array}$ & $\begin{array}{l}\text { Fraksi } \\
\text { berat } \\
\text { aditif }(\%)\end{array}$ & $\begin{array}{l}\text { Konduktivitas } \\
\text { termal komposit } \\
\text { PCM (W/m.K) }\end{array}$ & $\begin{array}{l}\text { Peningkat } \\
\text { an (kali) }\end{array}$ & Ref. \\
\hline RT44HC & 0,22 & $\begin{array}{l}\text { Expanded } \\
\text { graphite }\end{array}$ & 25 & - & $20-60$ & $\begin{array}{l}\text { (Ling dkk., } \\
\text { Fa15) }\end{array}$ \\
$\begin{array}{l}\text { Fatty acid } \\
\text { eutectics }\end{array}$ & $\begin{array}{l}0,119 / 0,191 \\
\text { (padat/cair) }\end{array}$ & $\begin{array}{l}\text { Expanded } \\
\text { graphite }\end{array}$ & 5 & $\begin{array}{l}0,149 / 0,292 \\
\text { (padat/cair) }\end{array}$ & $\begin{array}{l}1,25 / 1,54 \\
\text { (padat/cair }\end{array}$ & $\begin{array}{l}\text { (Tang dkk., } \\
2015)\end{array}$ \\
$\begin{array}{l}\text { Palmitic } \\
\text { acid }\end{array}$ & $\begin{array}{l}0,29 / 0,21 \\
\text { (padat/cair) }\end{array}$ & Graphene & 5 & $\begin{array}{l}2,75 / 2,54 \\
\text { (padat/cair) }\end{array}$ & 10 & (Mehrali \\
Paraffin & 0,2312 & Grafted CNTs & 4 & 0,7903 & 1,36 & $\begin{array}{l}\text { dkk., 2013) } \\
\text { (Xu dan Li. }\end{array}$ \\
Paraffin & 0,1264 & Nano graphite & 10 & 0,9362 & 7,41 & $\begin{array}{l}\text { 2014) } \\
\text { (Li, 2013) }\end{array}$ \\
\hline
\end{tabular}




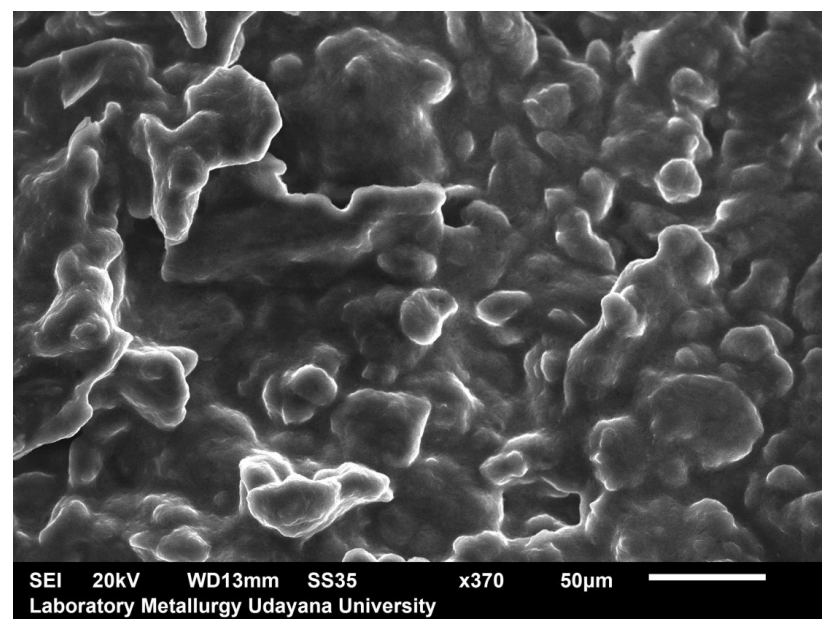

Gambar 7. Morfologi spesimen pada penambahan arang sekam padi $10 \%$

Gambar 7 menyajikan morfologi dari spesimen lemak sapi-arang sekam padi pada pembesaran 370x. Hasil foto SEM menunjukkan bahwa dengan metode pencampuran langsung dapat menghasilkan bentuk butiran dan lempengan dimana arang sekam padi dapat membungkus lemak sapi membentuk mikro kapsul. Metode pengkapsulan merupakan salah satu metode penggabungan bahan PCM untuk mencegah terjadinya kebocoran ketika bahan PCM mengalami perubahan fase.

\section{KESIMPULAN}

Hasil pengujian menunjukkan bahwa dengan penambahan arang sekam padi dapat meningkatkan konduktivitas termal PCM lemak sapi. Penambahan arang sekam padi sebesar $10 \%$ menghasilkan peningkatan 37 kali lipat dibandingkan dengan konduktivitas termal lemak sapi murni. Arang sekam padi dengan bahan dasar karbon dapat digunakan untuk meningkatkan konduktivitas termal bahan PCM.

\section{UCAPAN TERIMAKASIH}

Penulis mengucapkan terima kasih kepada semua pihak yang telah membantu baik berupa materi maupun pikiran sehingga penelitian dan paper ini dapat terselesaikan. Ucapan terima kasih juga penulis sampaiakn kepada Universitas Udayana atas bantuan dana penelitian melalui Penelitian Unggulan Program Studi tahun 2020 yang dibiayai melalui dana DIPA Universitas Udayana dan penulis mengapresiasi Program Studi Teknik Mesin Fakultas Teknik Universitas Udayana atas fasilitas yang dipergunakan dalam penelitian ini.

\section{DAFTAR NOTASI}

W : Daya listrik (watt)

$\mathrm{V}$ : Tegangan listrik (volt)

I : Arus listrik (ampere)

$\dot{q}: \mathrm{dQ} / \mathrm{dt}=$ laju perpindahan panas (Watt)

$\mathrm{k}$ : Koefisien perpindahan panas konduksi (Watt/m K)

A : Luas penampang benda uji (logam) $\left(\mathrm{m}^{2}\right)$

$\mathrm{dT}$ : Beda temperatur $(\mathrm{K})$

$\mathrm{dx}$ : Jarak antar titik uji $\left(\mathrm{T}_{1}\right.$ dan $\left.\mathrm{T}_{2}\right)$

\section{DAFTAR PUSTAKA}

Abu-Jdayil B., Mourad A.H., Hittini W., Hassan M., Hameedi S., 2019, Traditional, state-of-the-art and renewable thermal building insulation materials: An overview, Construction and Building Materials, 214, 709-735.

Astika I.M, Winaya I.N.S, Subagia A., Wirawan I.D.G, Santhiarsa I.K.G, Suarsana I.G.N., Priambadi I.K, Dwijana I.G.K, 2019, Phase change materials for building applications: A review, Proceeding SNTTM XVIII, 1-10. 
Bhattacharya M., Paramati S.R., Ozturk I., Bhattacharya S., 2016, The effect of renewable energy consumption on economic growth: Evidence from top 38 countries, Applied Energy, 162, 733741.

Cont, J., Holtberg P., Diefenderfer J., Larose A., Turnure J.T., Westfall L., 2016, International energy outlook 2016 with projections to 2040, USDOE Energy Information Administration (EIA), Washington, DC (United States).

Jeon J., Park J.H., Wi S., Yang S., Ok Y.S., Kim S., 2019, Latent heat storage biocomposites of phase change material-biochar as feasible eco-friendly building materials, Environmental research, 172, 637-648.

Li M., 2013, A nano-graphite/paraffin phase change material with high thermal conductivity. Applied energy, 106, 25-30.

Lin Y., Jia Y., Alva G., Fang G., 2018, Review on thermal conductivity enhancement, thermal properties and applications of phase change materials in thermal energy storage, Renewable and sustainable energy reviews, 82, 2730-2742.

Ling Z., Chen J., Xu T., Fang X., Gao X., Zhang Z., 2015, Thermal conductivity of an organic phase change material/expanded graphite composite across the phase change temperature range and a novel thermal conductivity model, Energy Conversion and Management, 102, 202-208.

Mehrali M., Latibari S.T., Mehrali M., Mahlia T.M.I., Metselaar H.S.C., Naghavi M.S., Sadeghinezhad E., Akhiani A.R., 2013, Preparation and characterization of palmitic acid/graphene nanoplatelets composite with remarkable thermal conductivity as a novel shape-stabilized phase change material, Applied Thermal Engineering, 61, 633-640.

Memon S.A., 2014, Phase change materials integrated in building walls: A state of the art review, Renewable and sustainable energy reviews, 31, 870-906.

Moraes D.S., Rocha T.L., Santin C.K., 2017, Microencapsulation of beef tallow by Sol-Gel method: synthesis and characterization.

Nazir H., Batool M., Osorio F.J.B., Isaza-Ruiz M., Xu X., Vignarooban K., Phelan P., Kannan A.M., 2019, Recent developments in phase change materials for energy storage applications: a review, International Journal of Heat and Mass Transfer, 129, 491-523.

Prusty J. K., Patro S.K., Basarkar S., 2016, Concrete using agro-waste as fine aggregate for sustainable built environment-A review, International Journal of Sustainable Built Environment, 5, 312-333.

Silva T., Vicente R., Rodrigues F., 2016, Literature review on the use of phase change materials in glazing and shading solutions, Renewable and Sustainable Energy Reviews, 53, 515-535.

Stram B.N., 2016, Key challenges to expanding renewable energy, Energy Policy, 96, 728-734.

Suarsana K., Astika I.M., Suprapto L., 2018, Karakterisasi konduktivitas termal dan kekerasan komposit aluminium matrik penguat hibrid $\mathrm{SiCw} / \mathrm{Al}_{2} \mathrm{O}_{3}$, Jurnal Muara Sains, Teknologi, Kedokteran dan Ilmu Kesehatan, 1, 108-116.

Tang F., Su D., Tang Y., Fang G., 2015, Synthesis and thermal properties of fatty acid eutectics and diatomite composites as shape-stabilized phase change materials with enhanced thermal conductivity, Solar Energy Materials and Solar Cells, 141, 218-224.

Wang C., Feng L., Li W., Zheng J., Tian W., Li X., 2012, Shape-stabilized phase change materials based on polyethylene glycol/porous carbon composite: the influence of the pore structure of the carbon materials, Solar Energy Materials and Solar Cells, 105, 21-26.

Xu B., Li Z., 2014, Paraffin/diatomite/multi-wall carbon nanotubes composite phase change material tailor-made for thermal energy storage cement-based composites, Energy, 72, 371-380. 